\title{
Using raster and vector data to identify objects for classify in flood risk. A case study: Raciborz
}

\author{
Mariusz Porczek ${ }^{1, *}$, Dorota Rucińska ${ }^{1}$, and Stanisław Lewiński ${ }^{2}$ \\ ${ }^{1}$ University of Warsaw, PolandFaculty of Geography and Regional Studies, 26/28 Krakowskie \\ Przedmieście St., 00-927 Warsaw, Poland \\ ${ }^{2}$ Space Research Centre of Polish Academy of Sciences, 18A Bartycka St., 00-716 \\ Warsaw, Poland
}

\begin{abstract}
The severe flood of 1997, which seriously affected Polish, Czech and German territories, gave impetus to research into the management of flood-prone areas. The material losses caused by the "Flood of the Millennium" totalled billions of Polish zloty. The extent of the disaster and of infrastructure repair costs changed the attitude of many branches of the economy, and of science. This is the direct result of consideration of the introduction of changes into spatial management and crisis management. At the same time, it focused the interest of many who were trained in analysing the vulnerability of land-use features to natural disasters such as floods. Research into the spatial distribution of geographic environmental features susceptible to flood in the Odra valley was conducted at the Faculty of Geography and Regional Studies of the University of Warsaw using Geographic Information Systems (GIS).

This study seeks to examine the possibility of adapting vector and raster data and using them for land-use classification in the context of risk of flood and inundation damage. The analysed area of the city and surrounding area of Raciborz, on the upper Odra River, is a case study for identifying objects and lands susceptible to natural hazards based on publicly available satellite databases of the highest resolution, which is a very important factor in the quality of further risk analyses for applied use.

The objective of the research was to create a $10 \times 10$-m-pixel raster network using raster data made available by ESA (Copernicus Land Monitoring Service) and vector data from Open Street Map.
\end{abstract}

\section{Introduction}

Changes in population size and increased population density in at-risk areas are directly responsible for the increasing losses resulting from hazardous natural events, including heavy rainfall and flooding. The potential for towns and neighbourhoods to expand into safe areas is becoming increasingly limited. Developers and local governments are attempting to

\footnotetext{
${ }^{*}$ Corresponding author: mt.porczek@uw.edu.pl
} 
remedy the housing crisis by developing residential areas in locations naturally unsuited for habitation [1]. Society is also adopting such land for agricultural or industrial requirements, due to the ever-growing needs of various sectors of the economy. There is increasing use of areas such as floodplains, artificial and natural polders, and escarpments, as well as of places either susceptible to landslide or surrounded by environmental features, which would hamper evacuation.

Such areas are particularly at risk. Natural hazards in areas of human activity lead to major losses, both societal and material. They can also cause irreversible damage to features of the natural environment and cultural heritage. Such events can slow local development as a result of falling investment and the frequent inability to rebuild damaged infrastructure and economic resources related to agriculture, industry or services. Therefore, spatial planning, which takes into account natural disasters and which adapts to places exposed to extreme natural events is also a very important aspect of risk management.

Studies of the spatial distribution of susceptible geographic environmental features on the floodplains of the Odra allowed for the creation of, inter alia, flood risk maps showing the extent of threat of material losses in the vicinity of Wrocław and Raciborz. The analysis used Geographic Information Systems and spatial data from scanned raster maps, which limited analysis to a maximum accuracy of a basic field of $250 \times 250 \mathrm{~m} \mathrm{[2].}$

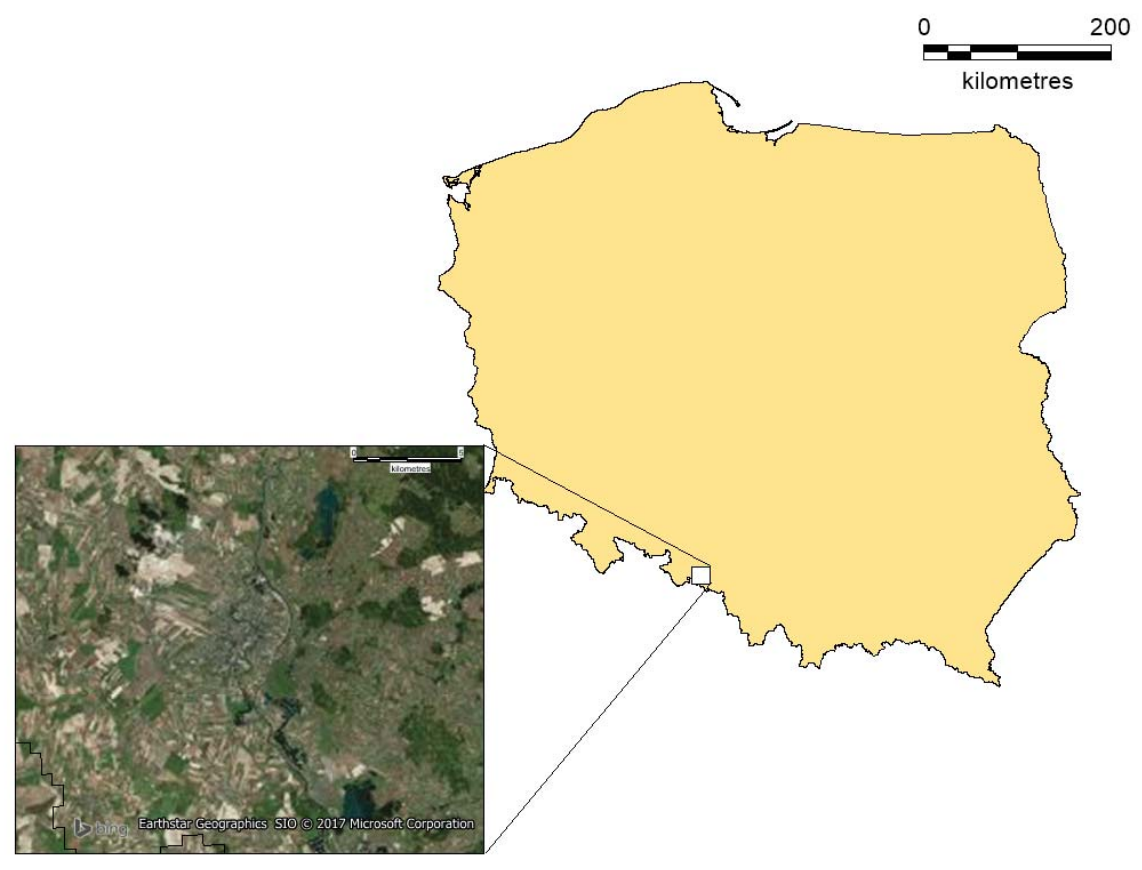

Fig. 1. Research area against the background of Poland.

According to land-use categories adopted in earlier studies [2] in this study has verified the possibility of an analogous analysis based on newer and more accurate spatial data from satellites dating to 2012 at the latest. Source data made available by the Copernicus Land Monitoring Service, Corine Land Cover (CLC) and High Resolution Layers (HR) and Open Street Map (OSM) were processed using GIS software in order to correlate them and obtain an accurate $10 \times 10$-m-pixel resolution map of land use determined. This allowed us to check the potential for adapting these publicly available data and using them in further disaster risk reduction studies. 


\section{Method}

Work on the use of GIS and remote sensing techniques to assess a variety of phenomena, including the geographical [3-7] are subject to continuous development from the 90s. These techniques are used in the analysis of various types of hazards [8-12]. Characteristics and discussion on the use of models, vector and raster is still valid [4, 5, 13-19].

The works on indicators of flood losses in Poland was conducting in the 1990s by Chojnacki [20-23]. He carried out the regionalization of indicators of topographic objects in terms of the estimated value of damages, dividing them into 11 types of investments: arable land, grassland, embankments, regulated banks, buildings, national roads, voivodship and municipal roads, railway tracks, bridges on national roads, on voivodship and municipal roads and on railway tracks. Probably because of the level of contemporary technology, objects were researched for the number of occurrences, not the total area. More recent studies similar to those described above are based on studies of determinants and development strategies of territorial units [24] or databases of vector objects $[2,25]$ which elaborated on the vulnerability scale of the development objects used in the study below.

At the time, within the framework of the EU Directive 2007/6/EC [26], the Institute of Meteorology and Water Management of the National Research Institute started implementing the ISOK program, under which created flood risk maps [27, 28]. The research on this project uses data derived from satellite imagery. At the same time, such research methods have attracted interest in the scientific community [29]. A new view of the problem is the use of both types of data that are made available to the public.

The analysis used a graded scale of 5 classes, from 0 to 4 , where 4 indicates the most negative impact of flooding on people and their lives, and 0 indicates no negative impact [2]. There are:

4 - residential or services buildings

3 - industrial or agricultural buildings, roads and railways

2 - arable land, orchards, recreational land

1 - forests, grasslands and wetlands

0 - standing or flowing water

This scale was used to classify land-use features presented on raster layers from satellite images further enhanced with spatial vector objects (also identified from satellite sources).

\section{Study area}

The Raciborz region was selected for its location in the Odra valley. The town is located on the upper course of the river among numerous tributaries. The town lands and surroundings have in many places been transformed to meet human needs. This is also true of its watercourses (e.g. the Ulga canal, which drains the area of Raciborz). To the south of the town, a canal connects the Odra basin with the Vistula basin.

The town was greatly affected by the flood of the millennium and is permanently at risk of flood and inundation. Each such event causes serious material losses for local inhabitants, companies and institutions. Raciborz is a medium-sized (pop. 56,000) historic town, which is densely built up and has a well developed urban infrastructure. Meanwhile, it is surrounded by the strictly agricultural lands which are typical of the Polish countryside. There are also forests and wetlands around the town. Together, these represent a typical land-use profile for Poland, making it an optimal area for research into flood risk reduction in the country. 


\section{Source material}

Three public-access online sources were selected. The base layer of the map was the Corine land cover map made available by the European Space Agency at the website Copernicus.eu [30]. The Corine Land Cover 2012 database (CLC 2012) is highly structured; it is divided into 44 categories of land-use features for Europe, of which 41 occur in the study area, including 13, which are significant to the present work. These categories were reclassified to the previously selected 5-point scale of losses (Table 1).

Table 1. Corine Land Cover 2012 classes, reclassified for the study (classes 0-4).

\begin{tabular}{|c|c|c|c|}
\hline \multicolumn{2}{|c|}{ Corine LC } & \multicolumn{2}{|c|}{ Study classification } \\
\hline 112 & Description & Class & Feature \\
\hline 121 & Industrial or commercial units & 3 & Industrial buildings \\
\hline 131 & Mineral extraction sites & 3 & Industrial buildings \\
\hline 142 & Sport and leisure facilities & 2 & Recreational land \\
\hline 211 & Non-irrigated arable land & 2 & Arable land \\
\hline 231 & Pastures & 1 & Grasslands \\
\hline 242 & Complex cultivation patterns & 2 & Arable land \\
\hline 243 & $\begin{array}{c}\text { Land occupied by agriculture with } \\
\text { natural vegetation }\end{array}$ & 2 & Arable land \\
\hline 311 & Broad-leaved forest & 1 & Forest \\
\hline 512 & Woniferous forest & 1 & Forest \\
\hline 512 & Wated forest & 0 & Flowing water \\
\hline
\end{tabular}

The database has a resolution of $100 \times 100 \mathrm{~m}$, which is insufficient for the current study, particularly in urban areas and areas with highly developed infrastructure. For this reason, data was selected from high-resolution thematic layers published - similarly as with the CLC - by the Copernicus Land Monitoring Service [31]. Raster layers available at $20 \times 20-\mathrm{m}$ resolution indicated Imperviousness, Forest Type, Grassland, Wetlands and Permanent 
Water Bodies. Their recency is also set at 2012, and they cover Europe (excluding Russia), Ukraine, Belarus and Moldova (similarly as with the CLC). All listed land-use features occur to at least a minimal extent in the research area (Fig. 2).

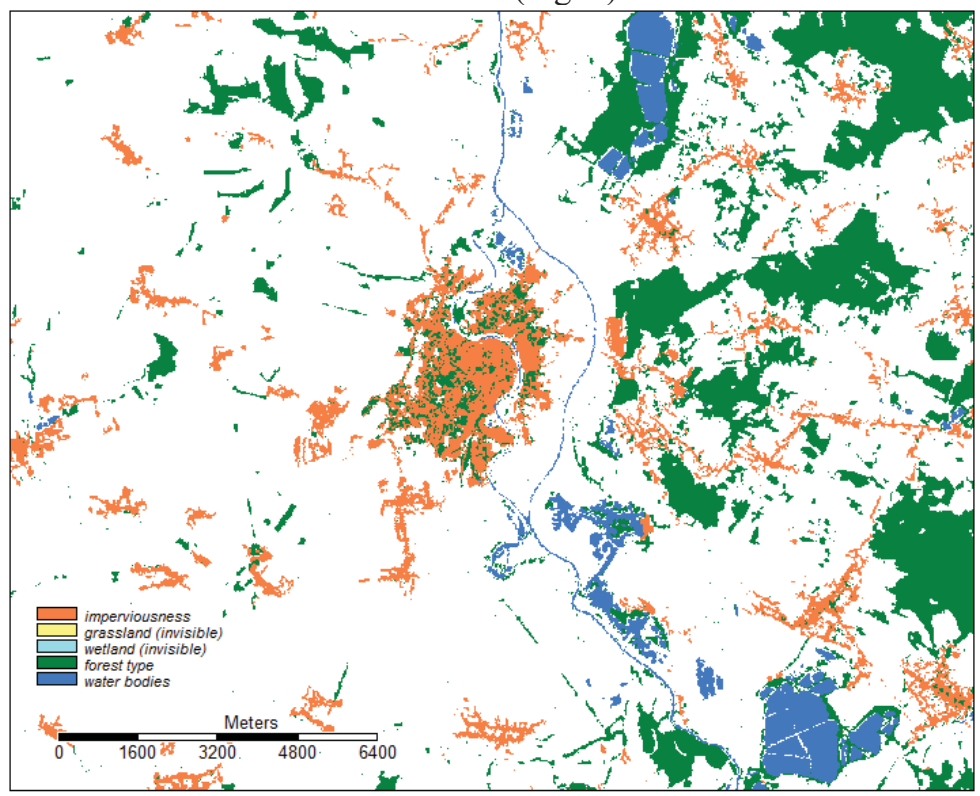

Fig. 2. High Resolution Layers (Copernicus Land Monitoring System).

The High Resolution Layers do not fully correspond to the classification adopted for the study, and hence their correlation to the generally adopted scale was difficult and incomplete (Table 2).

Table 2. High Resolution Layers reclassified for the study (classes 0-4).

\begin{tabular}{|c|c|c|}
\hline HR Layer & Class & Feature \\
\hline Imperviousness & 4,3 & $\begin{array}{c}\text { Residential buildings } \\
\text { Industrial buildings }\end{array}$ \\
\hline Forest type & 1 & Forest \\
\hline Grassland & 1 & Grasslands \\
\hline Wetlands & 1 & Wetlands \\
\hline Water Bodies & 0 & Water \\
\hline
\end{tabular}

In order to complete the gaps and reclassification of these selected raster layers for the land use classification study, the key features from the Open Street Map database [32] were made available in vector format. Layers from the OSM project present features identified from satellite imagery from, among others, Yahoo and Bing Maps. Their accuracy depends on the accuracy of the photo, although their resolution is decidedly greater than the resolution of the earlier selected raster layers.

Features that were difficult to identify on the raster images from other sources were 
selected from the Open Street Map database. Attention was given primarily to the linear feature layers (main roads, railways, and watercourses) not found in raster databases due to pixel resolution, but it was also decided to select residential areas due to the of dispersal of objects of this layer, which is not visible on lower-resolution raster layers (Fig. 3). These features were reclassified according to the aforementioned scale (Table 3).

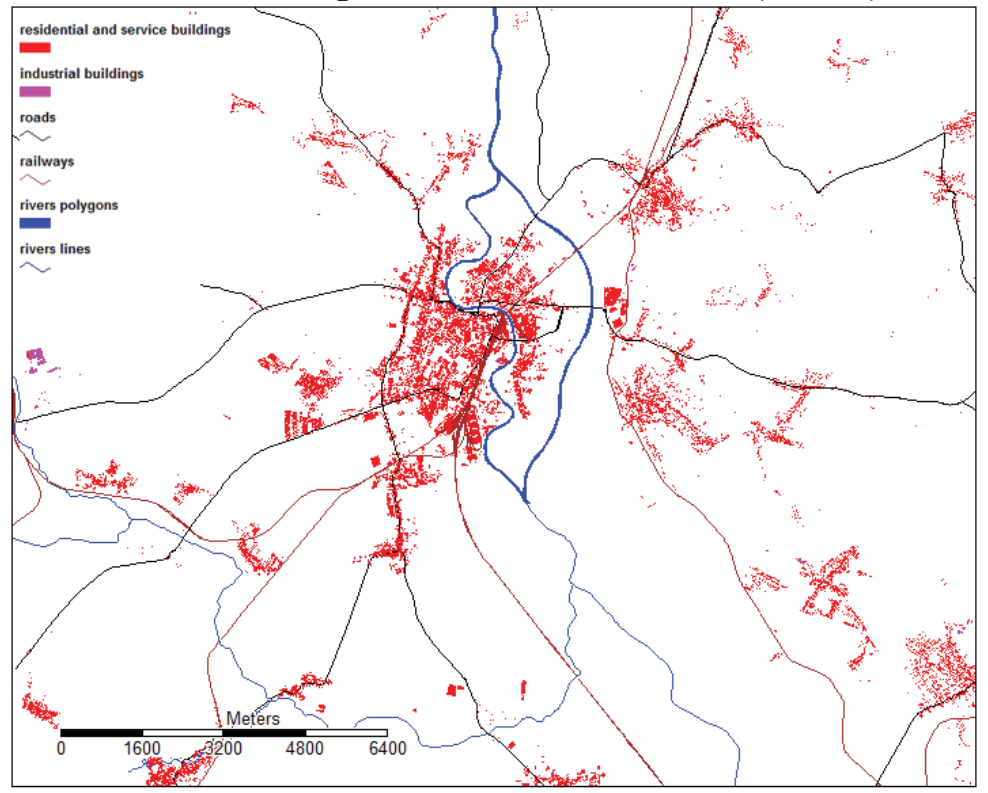

Fig. 3. Open Street Map layers selected for the study.

Table 3. Open Street Map objects reclassified for the study (classes 0-4).

\begin{tabular}{|c|c|c|c|}
\hline $\begin{array}{c}\text { Layer type } O S M \\
\text { attribute }\end{array}$ & OSM class & Class & Feature \\
\hline $\begin{array}{l}\text { Polygon } \\
\text { Building }\end{array}$ & $\begin{array}{c}\text { 'apartments' } \\
\text { 'chapel' } \\
\text { 'church' } \\
\text { 'civic' } \\
\text { 'college' } \\
\text { 'commercial' } \\
\text { 'detached' } \\
\text { 'dormitory' } \\
\text { 'farm' } \\
\text { 'farm_auxiliary' } \\
\text { 'house' } \\
\text { 'office' } \\
\text { 'residential' } \\
\text { 'retail' } \\
\text { 'school' } \\
\text { 'service' } \\
\text { 'shop' } \\
\text { 'train_station' } \\
\text { 'yes' }\end{array}$ & 4 & $\begin{array}{c}\text { Residential } \\
\text { buildings }\end{array}$ \\
\hline $\begin{array}{l}\text { Polygon } \\
\text { Building }\end{array}$ & $\begin{array}{c}\text { 'cowshed' } \\
\text { 'garage' } \\
\text { 'garages' } \\
\text { 'greenhouse' }\end{array}$ & 3 & $\begin{array}{l}\text { Industrial } \\
\text { buildings }\end{array}$ \\
\hline
\end{tabular}




\begin{tabular}{|c|c|c|c|}
\hline & $\begin{array}{c}\text { 'hut' } \\
\text { 'industrial"roof' } \\
\text { 'shed' } \\
\text { 'stable' } \\
\text { 'transformer_tow } \\
\text { er"transportation' } \\
\text { 'warehouse' } \\
\end{array}$ & & \\
\hline $\begin{array}{c}\text { Line } \\
Z \text { Z_order }\end{array}$ & $\begin{array}{l}5 \\
3\end{array}$ & 3 & Railway line \\
\hline $\begin{array}{l}\text { Line } \\
\text { Highway }\end{array}$ & $\begin{array}{c}\text { 'primary' } \\
\text { 'secondary' } \\
\text { 'secondary_link' }\end{array}$ & 3 & Main roads \\
\hline $\begin{array}{c}\text { Line } \\
\text { Waterway }\end{array}$ & $\begin{array}{l}\text { river } \\
\text { 'riverbank' }\end{array}$ & 0 & Flowing water \\
\hline $\begin{array}{l}\text { Polygon } \\
\text { Waterway }\end{array}$ & 'riverbank' & 0 & $\begin{array}{l}\text { Standing and } \\
\text { flowing water }\end{array}$ \\
\hline
\end{tabular}

\section{Data Processing}

Due to their varying resolutions and referencing systems (Table 4) all studied sources needed to be converted. The ETRS89 system (EPSG:3035), which corresponds to the Copernicus layer arrangement and a pixel resolution of $10 \times 10 \mathrm{~m}$, was selected. Conversion was performed using the SAGA GIS software according to the scheme of Figure 4.

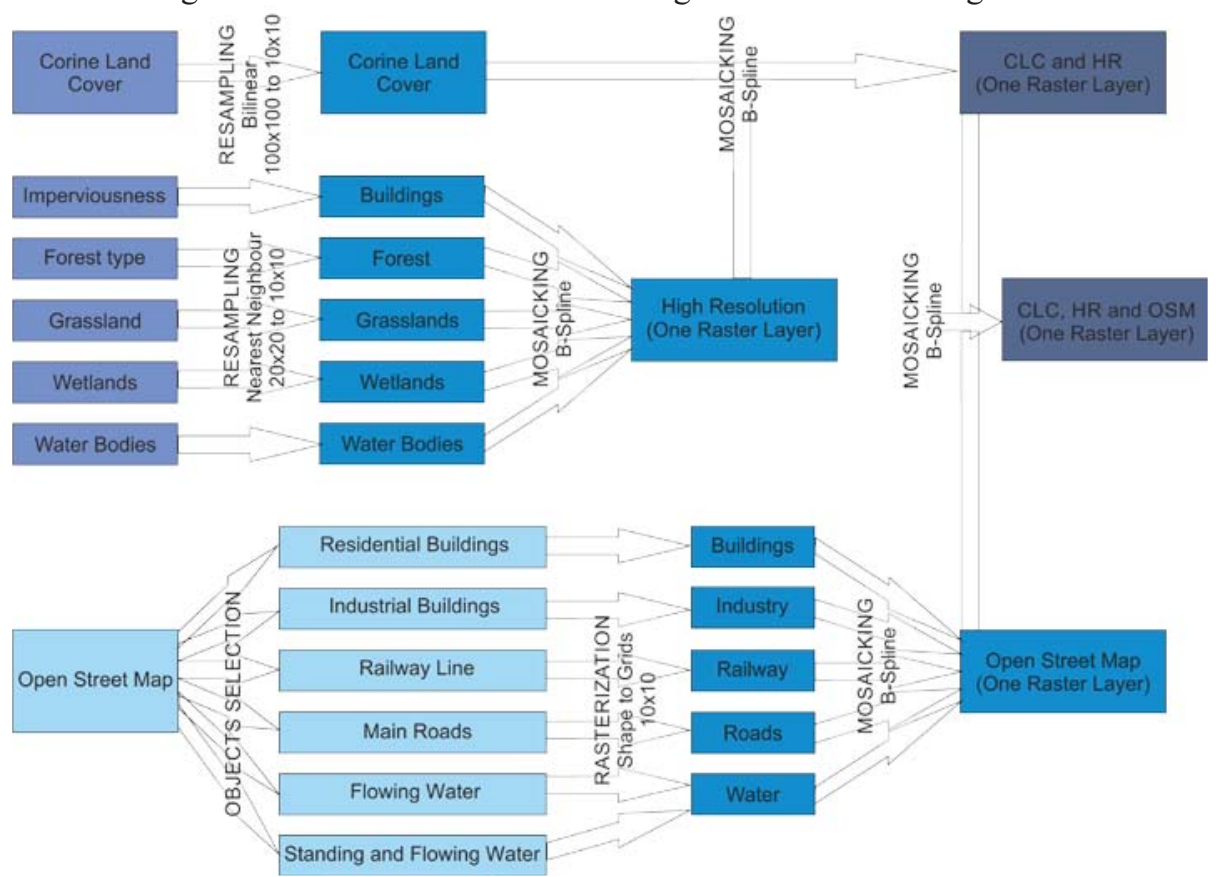

Fig. 4. Scheme of data processing adopted in SAGA GIS ${ }^{\dagger}$.

\footnotetext{
${ }^{\dagger}$ In resampling of HR Layers used a simply interpolation method (Nearest Neighbour), beacause this grid have only one atribute (value exist or not). In other more complicated layers adopted a B-Spline method, which is optimal in situation, when more value are adjacent.
} 
In the case of raster layers, a simple resampling was performed, which consisted of changing pixel size. The resultant maps were unchanged. Meanwhile, the Open Street Map layers, which remained in vector form were rasterised, maintaining the same parameters (Fig. $5)$.

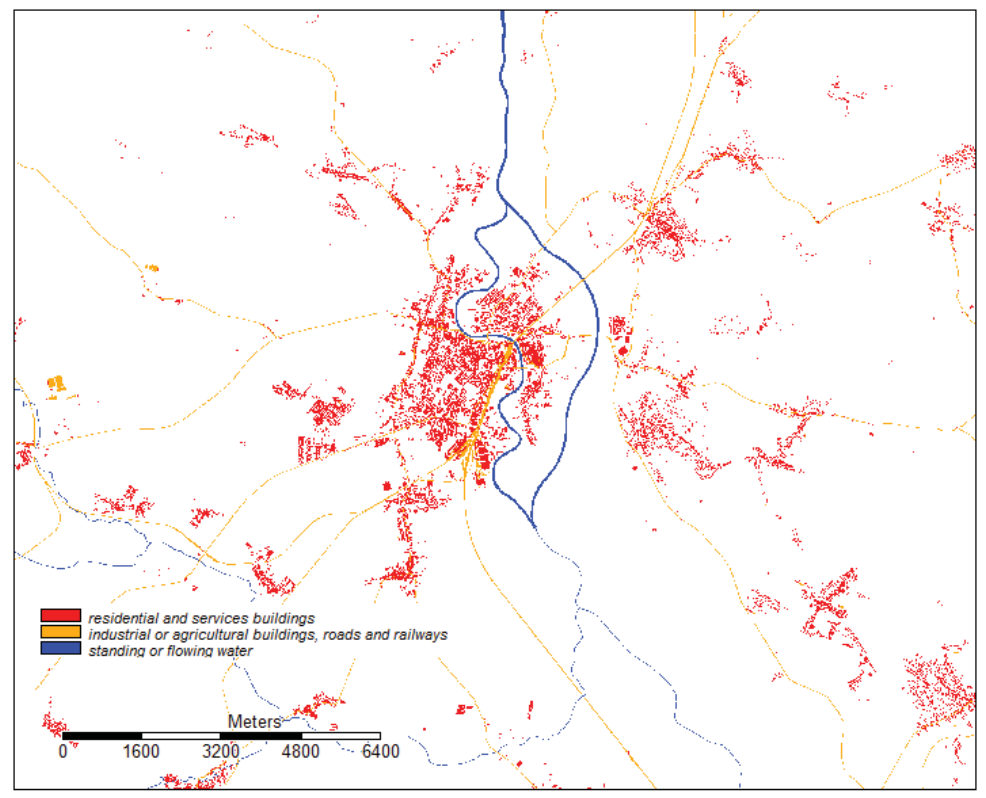

Fig. 5. Open Street Map layers reclassified to the study scale.

The next stage involved combining the layers while retaining the key features for study For reclassification for the study, the High Resolution layers were mosaicked, to combine five layers into one grid. The result contained features in the 0-4 scale of land use classes adopted in the study. A similar process was used for the Open Street Map layers to combine six layers. The reclassified Corine Land Cover data were left unchanged as a single ready layer.

In this way three land-use maps were obtained at the same resolution, of which only the Corine map is complete. Individual layers do not agree with each other in terms of land-use features. This is due to the resolution and methods of identifying features in the source layers.

In order to correctly identify features in the basic unit of study, which is the $10 \times 10$-metre pixel, a layer of hot spots, i.e. units with conflicting results, needed to be created. For error correction, combined grids were produced for CLC and HR layers. The resultant combined layer was a grid, which showed only the part common to the two layers, and which was reclassified so that the result values corresponded to the assumptions of the correlation of two overlapping classes (Table 4).

Table 4. List of CLC and HR layer classes.

\begin{tabular}{|c|c|c|}
\hline $\begin{array}{c}\text { HR class } \\
\text { (reclassified) }\end{array}$ & CLC class & New study class \\
\hline 4 & 112 & 4 \\
\hline 4 & 121 & 3 \\
\hline
\end{tabular}




\begin{tabular}{|c|c|c|}
\hline 4 & 142 & 2 \\
\hline 1 & 243 & 2 \\
\hline 1 & 311 & 1 \\
\hline 1 & 312 & 1 \\
\hline 1 & 231 & 1 \\
\hline 1 & 511 & 0 \\
\hline 0 & 512 & 0 \\
\hline 0 & & \\
\hline
\end{tabular}

The resultant reclassified grid of common parts was combined with the High Resolution Layers, again using Mosaicking, assuming the layer with the common parts as the main layer, and the HR layer as only supplementary (Fig. 6).

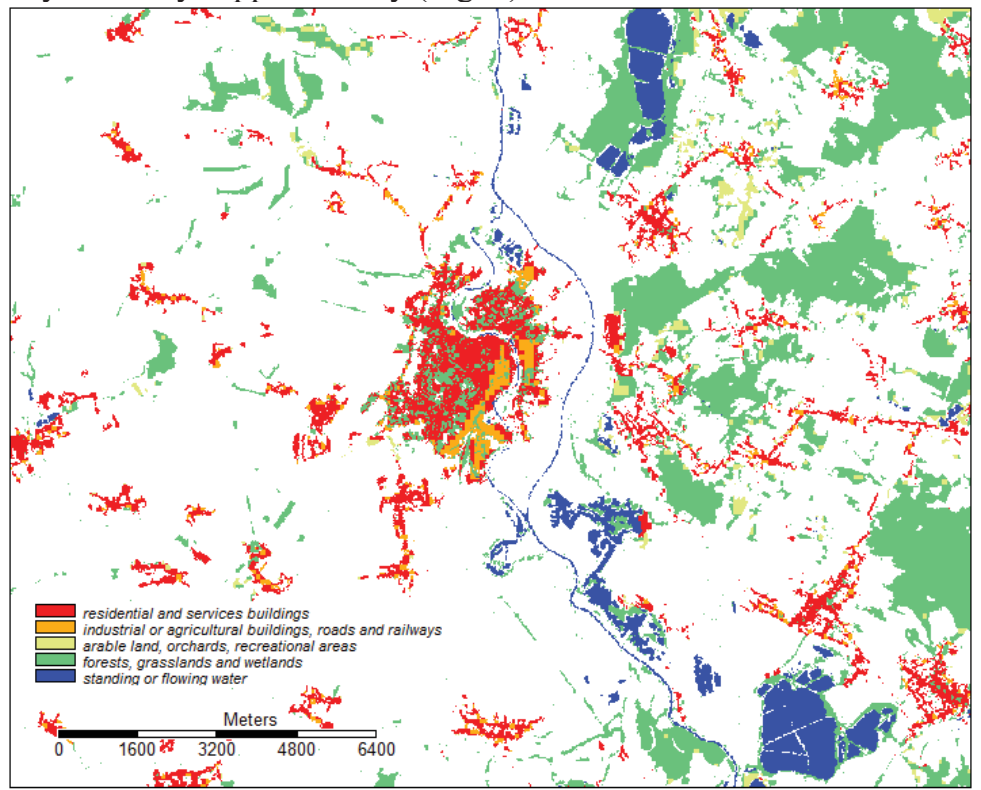

Fig. 6. Land use based on High Resolution Layers (Copernicus Land Monitoring System).

The method was repeated, adding the CLC grid to the resultant layer, this time assuming that this layer was supplementary. In this way, a full picture of land use was created, which did not identify linear features or individual buildings (Fig. 7). 


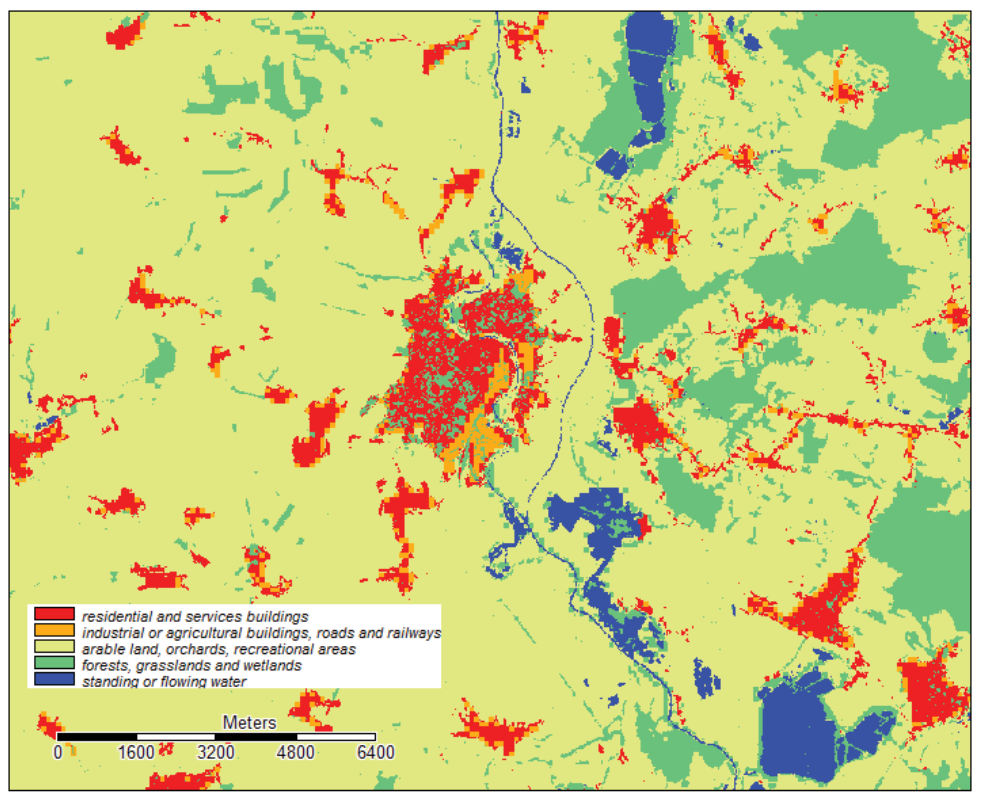

Fig. 7. Land use based on High Resolution Layers and Corine Land Cover (Copernicus Land Monitoring System).

The final research stage involved adding in Open Street Map objects to this newly created layer. Because of the insufficient building descriptions in the attribute table of the OSM layer it was assumed that buildings in an area designated as an industrial built-up area by previous analysis are industrial buildings and should therefore be identified as class 3 . To this end, combine grids was repeated to combine the previously indicated common part of the High Resolution and Corine layer with the OSM layer, according to the assumptions mentioned above (Table 5).

Table 5. List of CLC/HR and OSM layer classes.

\begin{tabular}{|c|c|c|}
\hline HR/CLC Class & OSM class & New study class \\
\hline 3 & 4 & 3 \\
\hline
\end{tabular}

The layer thus obtained was combined with the Open Street Map using Mosaicking (Fig. 7), and then with the previously obtained layer created from the Corine Land Cover and High Resolution Layers.

\section{Results}

The end product is a grid layer of land-use according to the classification adopted in the study. 


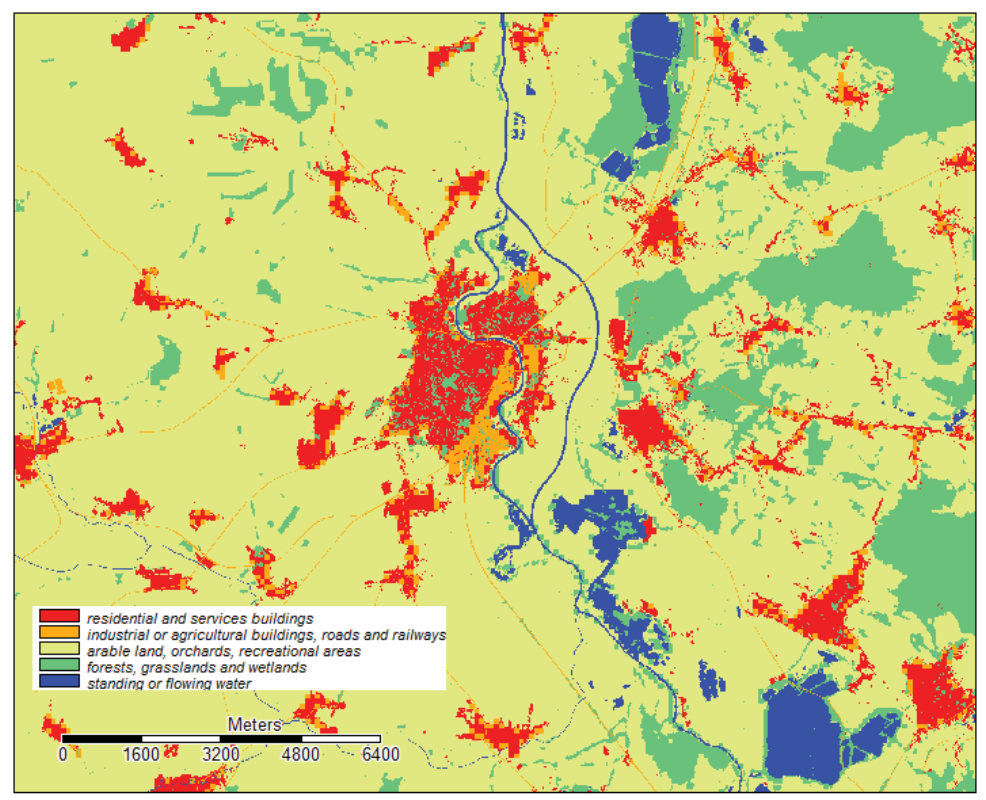

Fig. 8. Land use based on High Resolution Layers, Corine Land Cover (Copernicus Land Monitoring System) and Open Street Map.

All mosaicking steps were performed by B-Spline interpolation method to reduce errors when linking grids. Thus, despite the use of open source software and public data, the most accurate results could be preserved with possible methods [33].

\section{CONCLUSIONS}

During the processing of individual sources, it was noted that none of the tested databases individually met the criteria to allow their use in further studies. This is because each grid (CLC, HR and OSM) was incomplete, or the classification of features did not align with that used in flood-related research.

The Corine Land Cover 2012 layer is built on a scale, which deviates from the research standard. Although this database has almost all the desired features (except for line objects infrastructure and watercourses), its resolution does not allow for the exact identification of feature location.

High Resolution Layers, meanwhile, are a collection of grids that represent only some of the sought features, i.e. forests, grasslands, wetlands and water. The Imperviousness layer represents several classes of features, meaning it cannot be used without comparison against other sources.

The Open Street Map's incomplete description of features limits the degree of recognition of individual land-use features. The only linear features, which can be indentified without major obstacle are roads, railways and rivers. Surface features, such as buildings, were classified using numerous key words, and their attributes were frequently insufficient (e.g. question « building », answer « yes »). The remaining land-use features either do not occur or are insufficiently described.

The only solution is to mosaic all the described sources in order to obtain a single grid layer. This study paid close care to ensure that the results were precise and reflected reality. This allowed greater imaging quality to be obtained for land-cover components relevant to flood-risk management. 
The results layer (Fig. 8) shows land-use features for Raciborz and surrounding area as surface features from one of five possible classes to be used in further analyses. The $10 \times 10$ $\mathrm{m}$ resolution proposed in this study allows features to be identified, which are not accounted for in other studies due to their size but which are important to risk assessment.

The produced grid map is therefore the most accurate depiction of land use produced on the basis of data from widely available public sources. It is also a case study similar to studies on other regions of Poland and Europe.

\section{References}

1. Z.W. Kundzewicz, P. Kowalczak, The Climate Change and the Effects (Poznan: Kurpisz S.A., 2008)

2. D. Rucińska, Risk Analysis 35/2 (2015)

3. D.J. Wright, M.F.Goodchild, J.D. Proctor, Annals of the Association of American Geographers 87, 2 (1997)

4. J. Solan, Ocena różnorodności krajobrazu na podstawie analizy struktury przestrzennej roślinności (Prace Geograficzne, IGiPZ PAN, Warszawa 2002)

5. B. Hejmanowska, Archiwum Fotogrametrii, Kartografii i Teledetekcji 17b (2007)

6. M. Goodchild, Journal of Spatial Information Science 1 (2010)

7. C. Wang, J. Johnston, D. Vail, J. Dickinson, D. Putnam, Land 4 (2015)

8. A. Magnuszewski, Woda w badaniach geograficznych, T. Ciupa, R. Suligowski (ed.) (Instytut Geografii Uniwersytet Jana Kochanowskiego, Kielce, 2010)

9. M. Ogryzek, Acta Sci. Pol., Administratio Locorum 13, 4 (2014)

10. P. Pokojska, Prace i Studia Geograficzne 57, Warszawa (2015)

11. E. Woźniak, Teledetekcja Środowiska 51 (2014)

12. P. Werner, A. Magnuszewski, D. Rucińska, M. Porczek, Prace i Studia Geograficzne 57 (2015)

13. H. Goyal, C. Sharma, N. Joshi, International Journal of Computer Applications 169, 11 (2017)

14. W. Widacki, Wprowadzenie do Systemów Informacji Geograficzne (Wyd. Test, Kraków 2017)

15. M. Kistowski M. Iwańska, Systemy Informacji Geograficznej. Podstawy techniczne $i$ metodyczne. Przegląd pakietów oprogramowania $i$ zastosowań $w$ badaniach środowiska przyrodniczego (Bogucki Wydawnictwo Naukowe, Poznań 1997)

16. P. Longley, M.F. Goodchild, D. Maguire, D. Rhind, Geographic Information Systems and science (Jon Wiley \& Sons, Chichester, 2005)

17. R. Kot, Georóżnorodność - problémy jej oceny i zastosowania w ochronie i ksztaltowaniu środowiska na przykłądzie Fordońskiego odcinka Doliny Dolnej Wisty i jej otoczenia (Towarzystwo Naukow Toruń, UMK w Toruniu 2006)

18. B. Kuraś, Archiwum Fotogrametrii, Kartografii i Teledetekcji 17b (2007)

19. H. Gong, M. Simwanda, Y. Murayama, ISPRS Int. J. Geo-Inf. 6, 257 (2017)

20. J. Chojnacki, J. Rataj, Gospodarka Wodna 9/1975, Warsaw, SIGMA NOT (1975)

21. J. Chojnacki, Gospodarka Wodna 1/1993, Warsaw, SIGMA NOT (1993)

22. J. Chojnacki, Gospodarka Wodna 10/1994, Warsaw, SIGMA NOT (1994)

23. J. Chojnacki, H. Zawada, Gospodarka Wodna 3/1998, Warsaw, SIGMA NOT (1998) 
24. M. Borowska-Stefańska, Biuletyn Uniejowski 4/2015, Uniejów (2015)

25. M. Borowska-Stefańska, Zagospodarowanie terenów zagrożonych powodziami w województwie tódzkim (Łódź, Uniwersytet Łódzki 2015)

26. Directive 2007/60/EC of the European Parliament and of the Council of 23 October 2007 on the assessment and management of flood risks (2007)

27. Raport $z$ wykonania Wstepnej Oceny Ryzyka Powodziowego (Report of the Implrmentation of hazard risk maps and risk map offlood), Project ISOK (Informatyczny System Osłony Kraju przed Nadzwyczajnymi Zagrożeniami), title of the task 1.3.1: Wstęna Ocena Ryzyka Powodziowego (WORP), IMGW i KZGW (2011)

28. Z., Kurczyński, Archiwum Fotogrametrii, Kartografii i Teledetekcji 23, Wrocław (2012)

29. E. Drożdżal, M. Grabowski, K. Kondziołka, J. Olbracht, M. Piórecki, R. Radoń, A. Ryłko, Gospodarka Wodna 1/2009, Warsaw, SIGMA NOT (2009)

30. Corine Land Cover 2012, Copernicus Land Monitoring Service, copernicus.eu

31. High Resolution Layers, Copernicus Land Monitoring Service, copernicus.eu

32. Open Street Map Project, openstreetmap.org

33. S. Lee, G. Wolberg, S.Y. Shin, IEEE Transactions On Visualisation And Computer Graphics 3/3 (1997) 